\title{
Intensive Fruit Cultivation Technology of Citrus Fruits: High Density Planting: A Brief Review
}

\author{
Lal Bahadur Chhetri (Corresponding author) \\ Dept. of Horticulture, Post Graduate Program, Institute of Agriculture and Animal \\ Science, Tribhuvan University, Kirtipur, Kathmandu, Nepal \\ E-mail: chhetri.lalbah@gmail.com \\ Bishnu Prasad Kandel \\ Dept. of Plant Breeding, Post Graduate Program, Institute of Agriculture and Animal \\ Science, Tribhuvan University, Kirtipur, Kathmandu, Nepal \\ E-mail: bkandel33@gmail.com
}

Received: May 4, 2019

Accepted: May 27, 2019 Published: May 30, 2019

doi:10.5296/jas.v7i2.14865

URL: https://doi.org/10.5296/jas.v7i2.14865

\begin{abstract}
Sweat orange, grape fruit, lime, lemon and mandarin are the major citrus fruit cultivated in most of the countries. Less land and traditional citrus cultivation practice result low production as well as productivity especially in developing countries. This paper is reviewed with the aim of calling attentions of the concerned sectors by explaining benefits of high density planting technology over traditional system of planting in citrus fruit. More than forty research technical papers were critically reviewed focus on pruning practices, planting distance, dwarf rootstocks of citrus spp. and possible uses of plant growth regulators (retardants) used in citrus fruit. Annual pruning in recommend technique, use of dwarf rootstocks viz. trifoliate, troyer citrange, assam lemon etc, appropriate planting distance, use of plant growth regulators (Paclobutrazol and GA3) and nutrient management are the basic components for successful high density planting(HDP). HDP technology is gaining popularity in citrus because of earlier production and net returns, increasing land values and higher taxes of land, efficient use of nutrient and water due to greater root densities, efficient pesticidal application and easier weed control.
\end{abstract}

Keywords: citrus, growth regulators, high density planting, pruning, rootstocks

\section{Introduction}

Citrus is an evergreen flowering tree and shrub of Rutaceae family which height ranges from 
5 to 16 meter, 162 species of citrus are identified till date (Budathoki, 2004). High density planting is the production of fruits with more number of trees in given area than a conventional number of trees (G Tzul, 2016). Palmer (2004) explain high density planting as it is the new solution or option to overcome economic pressure adapted by dwarfing rootstocks and by better understanding of tree growth and behavior. Goswami et al. (2014) define it is the novel technique to obtain high productivity both in short and long duration crops. Increasing productivity in per unit area is important, with this aim high density planting was firstly adopted on apple in Europe during the end of the $19^{\text {th }}$ century (Lockard and Schneider, 1978; Sheheilah, 2013). Now, high density planting is adopted both in temperate and tropical fruits in developed countries. Shrestha (2010) mentioned two principles of high density planting as to make the best use of vertical and horizontal space per unit area and to harness maximum possible returns per unit of inputs. High density planting is highly successful in fruit like apple, pear, citrus, banana and pineapple (Lockard and Schneider, 1978).

Successful high density planting should be economically justifiable and also variety and rootstock should be better adopted (Tucker and Murano, 1990). Maximum utilization of space, sunlight, moisture, nutrient and weed control are keys to obtain higher yield per unit area under high density planting (Goswami et al., 1993). Because of lack of experimental data, recommendation and practices of planting in developing countries mandarin trees are planted in wider spacing (Shrestha, 2010). When citrus fruit price in market is high, sapling price is low, land is expensive and interest rates are low in banking institutions, high density planting gives more economic advantage (Palmer, 2004). The available land resource is limited, therefore to promote fruit industry crop intensification may be better option (Shrestha, 2010).

Generally, citrus trees are planted in rectangular and square methods with a dimension of $3 \mathrm{~m}$ x $4 \mathrm{~m}$ and $4 \mathrm{~m} \times 4 \mathrm{~m}$ respectively. Later, dimension increases to $6 \mathrm{~m} \times 8 \mathrm{~m}$ and $8 \mathrm{~m} \times 8 \mathrm{~m}$ after 15 - 20 years, respectively by thining out of trees (Sheheilah, 2013). The important five components of high density planting are dwarfing rootstocks and inter stocks, training and pruning, dwarf scion varieties, use of chemicals/ plant growth regulators and suitable crop management practices (Palmer, 2004; Goswami et al., 2014; G Tzul, 2016).Tucker and Wheaton (1978) reported vigor of tree (particular scion / rootstock combination), climate, soil fertility and drainage, water availability, use of chemicals and suitable crop management practices and market outlet as six important components of high density planting. The equipment used in high density planting technology for production and harvesting operation should be redesigned (reduced in size) as compared to the equipment used in normal density planting (Tucker and Murano, 1990). Improve in fruit quality, reduction of production cost, improve in precocity and reduction of spray drift are the reasons for adopting high density planting technology (Palmer, 2004).

Light penetration and light interception are most considering factors under high density planting (Westwood, 1988). Light is the one and only limiting factor in high density planting (G Tzul, 2016). It is the source of energy for photosynthesis, which influence flowering, fruit set and improve fruit quality and color development (Tucker et al., 1994). High yields with 
better fruit quality of mandarin orange can be obtained from high density planting if orchards have proper light distribution in bearing canopy (Goswami et al., 2014). Shading can cause smaller fruit size but it not a single factor that reduce fruit size, crop load, temperature, moisture and age of trees can also enhance this problem (Palmer and Wertheim, 1981). Now days, market is making demand with respect to fruit size and color therefore, more careful planning is necessary by grower of planting density, arrangement and cultivar vigour (Wertheim, 1981).

Root stock is one of the major factors that affect the tree size, quality and yield of the fruits (Tucker and Muraro, 1990). Pruning operations depends on factors like variety, age of plant, vigour, fruiting habits and growing condition (Tucker et al., 1994). Heading back and thining out are two types of practices in pruning operation of mandarin orange (Tucker et al., 1994). Heading back removes terminal parts and stimulate lateral buds growth whereas thining out encourages longer growth of terminal parts and creates better light penetration (Tucker et al., 1994). Sprouts, weak branches and twigs, crossing or dead branches are removed to allow more light in the canopy during pruning. The sprouts originated from main trunk should be removed the trees should be in shape of skirt after pruning. February - April (spring) is the best time for annual citrus pruning (Wright and Kelly, 2008).

To reduce the harvesting cost proportion in total production cost, modern tree spacing have been developed by controlling tree size and to reduce the gestation period low spacing can effective (Cary, 1977). Citrus trees adapt wide range of spacing allocations, but maximum return is generated when trees perform well within allocated space (Wheaton et al., 1995). More production or productivity can be achieved by reducing the space between the trees but less space can affect the quality of fruits so adequate space should be managed for light penetration (Koptiz, 1976). Mc Carry et al. (1969) reported that fruit bearing foliage is more important than tree density. Therefore, trees should be guided to provide greatest possible fruit bearing volume per unit area.

There is no necessity of adopting high density planting to the farmer if existing trees gives adequate performance, lack of dwarf rootstocks, poor quality of saplings, lack of experience and lack of an innovative culture (Palmer, 2004). Large trees with excessive vigor are becoming less popular among modern citrus growers. The reason of unpopularity of seed propagated plants because of large size trees which increases more manual labor cost as compared to high density planting (Cary, 1977).

This paper was prepared to review the information from all available resources i.e. journals, annual reports, proceedings, books, etc published by different Researchers, Authors, Professors as well as research centers and stations. More than forty research papers were collected and intensive review was made. Collected information were systematically arranged into different subheadings namely; pruning, planting distance, dwarfing rootstocks and use of growth regulators. 


\section{High Density Planting}

High density planting is advantage over traditional system of citrus plantation, that is in tree number, fruit bearing characters, production, management way, labor requirement, production cost and in quality (Singh and Singh, 2018). The key factors of high density planting is dwarfing rootstocks, tree row structure a hedge and $100 \%$ mechanized harvesting (Bordas et.al., 2012). Boswell et al. (1975) reported that high density planting in Washington Navel Orange increase yield in early year of production. Albert (1990) reported that citrus greening disease was counter by adopting high density planting in Thailand.

The height of trees is higher in high density planting as compare to low density planting because of competition effect on light between the trees but plant canopy is greater in low density planting than high density planting because of less competition of space, plants can grow in its original shape. Similar result was found in kinnow mandarin by Nawaj et. al. (2007) in Punjab province of Pakistan.

\section{Pruning}

Slow growing species of citrus respond more favorable to pruning and also easy to maintain size of tree (Singh and Singh, 2018). Pruning adjust tree shape, balance ratio between frame work and bearing canopy, alter top/root ratio and also alter carbohydrate status of plant (Tucker et al., 1994). Ghosh (2015) reported that $25 \mathrm{~cm}$ pruning from terminal portion of lemon cv. Assaam lemon shoot (light pruning) gives the better yield than less centimeter pruning and no pruning. Topping and hedging (pruning), increasing tree density and use of dwarf rootstocks are the major approaches to control the size of citrus trees. If $10 \%$ tree canopy is reduced from the crowded orchard, annual yield will be increased significantly (Cary, 1977).

Secatures (hand pruners), looper and pruning are the common equipment, should be sterilize. $3 \%$ sodium hypochloride can be used as sterlising agent. Trees should be pruned after severe winter - before starting of summer. If trees are pruned in early spring, it stimulate more growth of flush which susceptible to frost. The expose parts after pruning should be protected from sun burn by applying paints (Fake, 2012).

\subsection{Techniques in Pruning}

\subsubsection{Suckering}

Especially trifoliate rootstock (Poncirus trifoliate) has throns in rootstock which can be hazardous to worker and can damage the thin mandarin peel (Fake, 2012).

\subsubsection{Gourmands (Water sprouts)}

They grow rapidly and use huge nutrients and water amounts and remains in vegetative for several years so, they should be removed (Fake, 2012).

\subsubsection{Skirting up}

When there is heavy load, the skirt branches bend and fruit might touch the ground which can 
induces soil borne diseases. Therefore, trees especially in Satusma mandarin should be skirted up to $75 \mathrm{~cm}$ above the ground every year (Fake, 2012).

\subsubsection{Canopy Thining}

For better fruit quality canopy thining is necessary from light penetration view. It should be done every year (Fake, 2012). Pruning promotes the penetration of sunlight in the tree canopy resulting leaves, shoots and good quality fruits development. Higher rate of transpiration and respiration produce more carbohydrates when leaf exposed to sunlight. Hence, tree becomes more healthy and robust (Klerk, 2017).

\subsubsection{Reducing Tree Height}

Reducing tree height (dwarf cultivars of citrus) is the basis component for high density planting. Severe pruning may kill the tree. Generally, not more than a third of height should be reduced (Fake, 2012). In high density planting hedge height should be maximum of $2.5 \mathrm{~m}$, $1 \mathrm{~m}$ width and $0.7 \mathrm{~m}$ minimum the base of the trunk tree of branches (Bordas et. el., 2012).

Schumann et al. (2012) reported that when one side of the citrus tree is aggressively hedged but another side is hedge less aggressively then other side, it helps to maintain more consistent fruit bearing. Light pruning ( $25 \%$ from terminal shoot) with $75 \%$ organic fertilizer gives best yield by Assam lemon (Citrus limon Burm) under high density planting (Ghosh et al., 2016).

In last twenty years of pruning history, it becomes common for citrus grove to manage under high density planting technology. In past farmers thining tree (removing tree) when orchard become dense but now a days, farmers maintain the size of tree by pruning annually (Smith, 2002).

Citrus pest like sucking insects (Scale insects and Mealy bugs) are controlled by pruning since they loves dense canopies, not only that pruning overcome alternate bearing of mandarin to certain degree. Pruning after light bearing years allows the plant to replenish its food reserves and transfer to a more balanced bearing habit (Fake, 2012).

Small trees are comparatively better than large trees in capturing and converting light in to fruits and also enhance the better aeration in the orchards (Vandan et.al., 2017).

\subsection{Planting Distance}

There has always been discussion regarding the spacing in citrus trees to maximize net returns. Japanese cultivar of citrus are generally dwarf and planting distance manage at spacing of 9 feet x 9 feet $(2.74 \mathrm{~m} \times 2.74 \mathrm{~m})$ which is refer as high density planting. In California state of USA planting distance maintained at 20 feet x 22 feet $(6.10 \mathrm{~m} \mathrm{X} 6.71 \mathrm{~m})$, which is consider normal planting or traditional planting density (Tucker and Wheaton, 1978).

If suitable variety of rootstocks is used 800 plants / acre $\left(4046.856 \mathrm{~m}^{2}\right)$ can be successfully grown. In normal condition 140- 300 trees are planted in one acre (Tucker and Muraro, 1990). Singh and Singh (2018) mentioned that planting of citrus (kinnow) at spacing $1.8 \mathrm{~m} \times 1.8 \mathrm{~m}$ (3000 plant/hectare) gives 20 ton/hectare which is $200 \%$ more yield than traditional yield. 
Shrestha (2010) reported Troyer citrange is very effective in high density planting can be planted in $1.8 \times 1.8 \mathrm{~m}$. Cary (1977) reported that when 701 tree/ha was planted as high density planting in citrus, it gives yield more than 60 ton/ha

Boswell et al. (1968) study Washington Naval, eleven densities in California for ten years and reported that highest return was from 445 trees/ha but benefit was higher in 890 trees/hectare in initial years, which signifies high density planting gives more economic advantage in earlier year than late year of planting. Different researcher recommend different spacing with different result viz. Wheaton et al. (1994) recommend 2020 trees/hectare (1.0 m x $3.3 \mathrm{~m}$ ) for orange supp stop Singh et al., (2004) recommend 23 feet x 23 feet. Bordas et al. (2012) reported that using new dwarf root stock and spacing $3.5 \mathrm{~m}-4 \mathrm{~m} \times 1 \mathrm{~m}-2 \mathrm{~m}$ gives higher and regular yield with improved fruit quality by reducing cost of harvesting. Dogar et al. (2017) conducted experiment of three planting distance 11 feet $x 22$ feet, 11 feet x 11 feet and 22 feet $x 22$ feet. Higher yield was reported from 11 feet x 22 feet and also reported more flowering in 11 feet $x 11$ feet but yield was low than 11 feet $x 22$ feet because of higher fruit drop.

Falivene (2018) compare three densities planting of citrus as,

a. Traditional tree density: 440 trees/hectare

b. Double row: 952 trees /hectare

c. Standard row: 600 trees/hectare

When annual pruning practice was implemented yield increases to $55 \mathrm{Mt} / \mathrm{hectare}$ in standard row and $63 \mathrm{Mt} /$ hectare in double row planting. If no annual pruning practices, yield decreases to $15-20 \mathrm{Mt} / \mathrm{hectare}$ in both double row and in standard row.

\subsection{Dwarfing Rootstocks}

Citrus rootstocks have varied effects on scion vigour and size, fruit yield and quality and tolerance to various biotic and abiotic stresses. These also differ in their adaptability to various soils and micorrhizal dependency (Castle, 1987; Ford, 1959; Nemec, 1978).

More than twenty horticultural and pathological characters of citrus trees are governed by root stock (Tucker et al., 1994). Dwarf rootstocks develop small canopies with more fruit per unit area canopy in scion in comparison to vigorous rootstocks (Wheaton et al., 1994). Cleoptra mandarin was the common root stocks of mandarin groups of Florida Citrus industry during 1970s (Tucker et al., 1994).

Castle et al. (1987) reported Hybrid of Rangpur lime (Citrus limonia) and Troyer Citrange (Citrus sinensis and Poncirus trifoliate) are well known dwarf rootstocks for citrus group. Shrestha and Verma (1998) mentioned trifoliate orange as very good dwarf rootstocks for citrus and easily available in citrus growing areas of world. Simlarly, Shrestha (2010) reported Troyer citrange, Mayer lemon, Ponderosa lemon, Kumquat and Kawanowasaas dwarf cultivars of citrus from South Asia.

Askhkenazi et al. (1993) mentioned fly dragon (Poncirus trifoliate var. monstrosa) as best 
known true dwarf rootstock among Citrus spp. and growth rate is slow in young stage, have small size in bearing stage. Therefore, it may be the best option for rootstock in high density planting of citrus fruits. The use of Fly Dragon Trifoliate Orange (Poncirus trifoliate var. monstrosa) also overcome the problem of late bearing of fruit and low productivity and induce small trees and early production character (Mademba-Sy et. al., 2012).

A few Forner-Alcaide hybrid selections exist which also confer a dwarfing response on scions, in particular FA 517 and FA 418, whose agronomical behaviour has been tested under field conditions Both rootstocks show lower canopy volumes, but higher yield efficiency when compared with Carrizo citrange, the most extended citrus rootstock in Spain (Leuga et al., 2013) .Moreover, they produce good fruit quality and optimal response when cultured in alkaline soils, one of the main factors that limits crops in Spanish soils (Leuga et al., 2013, Leuga et al., 2014 and Forner-Giner et al., 2014).

Poncirus trifoliate or citrange (Poncirus trifoliate $\mathrm{x}$ orange hybrid) are better rootstock with Valencia orange (Citus sinensis (L) osb.) for high density planting. This method of propagation for high density planting is highly economical than traditional planting (Hutton, 1986). Fly dragon is the new citrus rootstock considered to be dwarf rootstock in the world. Along with dwarfness it is resistance to gumossis, tristeza virus tolerance, cold hardiness and have high quality fruits. Ferlito et al. (2016) reported 'Flying Dragon' and 'Rubidoux' trifoliate orange reduced plant growth when they are used as rootstock in Citrus spp.. They are suitable for high density planting than other rootstock like sour orange (C. aurantium), Swingle citrumelo (C. paradise) x Poncirus trifoliate, Volkamer lemon (C. volkameriana) and troyer. Trifoliate orange have characters of small trees, high yield, tolerant to foot rot and tristeza virus and with good quality fruit so, consider as best suitable for oranges group (Goswami et al., 2017). Goswmi et al. (2017) reported Feronia limonia was proved to be a highly dwarfing and precocious citrus root stock and suitable for high density planting. Tucker et al., (1994) described trifoliate orange (Flying dragon) as very dwarf rootstock suitable for high density planting and dooryard planting. Trifoliata (Poncirus trifoliate) cannot tolerate high $\mathrm{pH}$ and saline soil but grows best in heavy soil with high fruit quality (Skewes, 2016).

IARI, New Delhi identified troyer citrange as dwarf and karna khatta as semi dwarf rootstock for citrus spp. in Indian context (Goswami et.al., 2014). Assam lemon (Citrus limon Burm) is the important dwarf cultivars of citrus for north India, fruiting three times in a year (Singh and Singh, 2018). Singh and Singh (2018) mentioned dwarf root stock for citrus namely Citrangequat, Feronia, Seveeriniav boxifolia, trifoliate orange, Sour orange and citrange for Indain sub continent.

United State Department of Agriculture (USDA), Agriculture Research Service (ARS) developed two new root stock in between the year 2001 and 2010, namely US-812 and US-897 for high density planting which are relatively tolerance to Haunglongbing (HLB) also (Bowman et.al., 2016).

Growth reduction induced by dwarfing rootstocks has been associated with lower leaf and stem water potentials in the scions grafted onto them compared with those grafted onto vigorous rootstocks, probably due to high hydraulic conductivity resistance, which may cause 
water deficit in leaves during periods of high evaporative demand and stomata closure (Martínez-Alcántara et al., 2013). Consequently, dwarfing rootstocks are poorly able to transport water from soil to stems (Basile et al., 2003).

Bar - Joseph (1983) reported next citrus dwarfing techniques by using graft transmissible dwarfing agent \#225t. This citrus viroids cause dwarfness on grape fruit and blanco.

Incompatible rootstock and scion can be used to induce dwarfness in fruit trees but this techniques is not still adopted in high density planting (Singh and Singh, 2018).

Micro budding of Mars orange, Grape fruit, Ponderosa lemon and Satsuma mandarin on sour orange root stock also gives better performance in high density planting or ultra high density planting of Citrus species (Sakaria and Tao, 2000).

\subsection{Use of Growth Regulators}

Applying foliar spray of hormone to tall trees with dense canopy is problematic and ineffective, because spray cannot penetrate dense canopy (Klerk, 2017). Use of growth regulators induce dormancy to reduce vegetative growth, delay flowering and reduce fruit drop. Commercially available growth retardants viz. ECC, Ancymidal, Paclobutrazol, B-9 (Phosphon-D), Chloromquat check the vegetative growth of fruit trees (Singh and Singh, 2018).

Fruits drop in fruit is due to malnutrition, moisture stress, excessive insect pest attack and due to hormonal imbalance (Jhade, 2016). When concentration of auxin decrease and ABA concentration increases, it causes fruit drop in citrus trees (Browning, 1986). Almeida et al. (2004) reported auxin and gibberllins controlled fruit drop and also improve quality of fruit.2,4-D and GA3 applied combinely or alone at different stages improves fruiting behavior of Nagpur mandarin (Jhade,2016). Soil application Paclobutrazol (growth retardants) improves flowering in citrus fruit but reduce the growth of new shoots (Jhade, 2016). Tmelselvi and Baskaran (2004) mentioned that Paclobutrazol application at $2.50 \mathrm{a} . \mathrm{i} /$ tree also increases $\mathrm{N}$ content of leaf.

In Valencia orange 2- Chloroethyl Phosphonic acid $1000 \mathrm{mg} / \mathrm{l}$, Alar (Succinic acid, 2Di-methyl hydrazide) $2500 \mathrm{mg} / \mathrm{l}$ and Cycocel $5000 \mathrm{mg} / \mathrm{l}$ increases flower induction (Gonzales and Borroto, 1987). Salomon (1981) reported, the supply of 2- Chloroethyl trimethyl ammonium chloride (CCC) in young lemon trees through root irrigation induced an early start of flower and improved fruit set by causing dwarfness to plant.

\section{Conclusion}

Tree size and vigor are important characters from plant density view. Commercial farmer interest is increasing towards smaller, less vigorous trees which are efficient in economics and more suitable for high density planting. The factors viz. rootstock, spacing, tree height, pruning system are integrated by light interception. Higher the light interception by plant higher will be the yield. Closer planting, taller trees and closer row spacing increased light interception. Good light distribution also promotes the higher yield per unit area. For successful farming there should be good light interception and good light distribution. Grove planted in a north and south direction, ensures better light distribution. 
It should be clear that not all locations and tree combinations are suitable for high density plantings. Annual pruning in recommend technique, use of dwarf rootstocks viz. trifoliate, troyer citrange, assam lemon etc, proper spacing, use of plant growth regulators (Paclobutrazol and GA3) and nutrient management are the basic components for successful high density planting. It has been proved traditional density planting on a 20' x 20' spacing would take 12 years to pay back all initial development costs (considering average returns). The same variety planted on a 10' x 20' would pay back in eight years. Because these numbers have been proven valid, many growers today face the challenge of how to manage the high density grove they have planted.

High density planting technology is gaining popularity because of earlier production and net returns, increasing land values and higher taxes of land, efficient use of nutrient and water due to greater root densities efficient pesticidal application and easier weed control.

\section{References}

Albert, B. (1990). Citrus Disease and Their Management. In. Proc. of the fourth international Asia Pacific Conference on Citrus Rehabilitation.Chanmai, Thialand.

Almeida, I., Leiti, I. M., Rodrigues, J. D., \& Ono, E. O. (2004). Application of plant growth regulators at pre-harvest for fruit development of PERA oranges. Braz. Arch. Bio. Technol., 47(4), 658-662. https://doi.org/10.1590/S1516-89132004000400003

Basile, B., Marsal, J., \& DeJong, T. M. (2003). Daily shoot extension growth of peach trees growing on rootstocks that reduce scion growth is related to daily dynamics of stem water potential. Tree Physiol. 23:695-704. https://doi.org/10.1093/treephys/23.10.695

Bordas, M., Torrents, J., Arenas, F. J., \& Hervalejo, A. (2012). High density plantation system of the spanish citrus industry. Acta Horticulture. 965, 123-130. https://doi.org/10.17660/ActaHortic.2012.965.15

Bowman, K. D., Faulkner, L., \& Kesinger, M. (2016). New Citrus Rootstocks Released by USDA 2001-2010: Field Performance and Nursery Characteristics. American Society for Horticulture Science. 51(10), 1208-1214. https://doi.org/10.21273/HORTSCI10970-16

Browning, G. (1986). The physiology of fruit set. In: manipulation of fruiting. (Ed): C. U. Wright and Butter Wareh, 19, 5-198.

Budathoki, K. (2004). Citrus diversity, their characterization and evaluation in Nepal. Proceeding of the Forth National Workshop on Horticulture. Advances of Horticulture Research in Nepal

Cary, P. R. (1977). New Concepts in Citrus tree spacing and pruning practices. Proceeding of International of. Society of citriculture 1, 162-165.

Castle, W. S. (1987). In: Rootstocks for fruit crops (Rom and Carlson ed.), 361-399.

Castle, W. S., Youtsey, C. O., \& Hutchison, D. J. (1987). Rangpur x Troyer citrange.A hybrid citrus rootstock for closely space trees. Proceeding of. Florida. State Horticulture Society. 99: 33-35. 
Dogar, W. A., Khan, A. A., Ahmed, S., Tariq, S., Ahmad, M., Imran, M., ...Khan, N. (2017). Study to determine the effects of high density plantation on growth and yield of citrus. Sarhad Journal of Agriculture. 33(2), 315-319.

https://doi.org/10.17582/journal.sja/2017/33.2.315.319

Fake, C. (2012). Pruning Citrus, University of California, Cooperative extension. USA

Fard, H. W. (1959). Proceeding: American Society of Horticulture Science. 74, 313-321. https://doi.org/10.2307/2146272

Ferlito, F., Torrisi, B., Cicciarello, G., Russo, G., PietroPaolo, D., Allegra, M., ... Roccuzzo, G. (2016). Effects of seven rootstocks on the performance of Citrus medica L. ('Diamante'). Acta Horticulture. 1130, 437-444. https://doi.org/10.17660/ActaHortic.2016.1130.65

Forner-Giner, M. A., Rodriguez-Gamir, J., Martinez-Alcantara, B., Quiñones, A., Iglesias, E. Primo-Millo, D. J., \& Forner, J. (2014). Performance of Navel orange trees grafted onto two new dwarfing rootstocks (Forner-Alcaide 517 and Forner-Alcaide 418). Sci Hortic. 179, 376-387. https://doi.org/10.1016/j.scienta.2014.07.032

G Tzul, L. (2016). High Density Planting in Orange. Belize Agriculture report, 31.

Ghosh, A. (2015). Effect of pruning and nutrient management on growth and yield of lemon cv. Assam Lemon (Citrus limon Burm), MS (Horticulture) Thesis, Deparmtent of Pomology and Post Harvest Technology, Faculty of Horticuture, uttarbangakrishiviswavidyalaya, West Bengal, India

Ghosh, A., Dey, K., Bhowmick, N., Medda, P. S., \&Ghosh, S. K. (2016). Impact of Different Pruning Severity and Nutrient Management on Growth and Yield of Lemon cv. Assam Lemon (Citrus limon Burm.). Vegetos 29(1). https://doi.org/10.5958/2229-4473.2016.00007.0

Gonzales, J. L., \& Borroto, C. (1987). Use of Plant Growth Regulators to Control Flowering in Citrus. Biologia Plantarum, 29(5), 342-349. https://doi.org/10.1007/BF02886611

Goswami, A. K., Singh, S. K., Srivastav, M., Nagaraj, A., Prakash, J., \& Kumar, C. (2017). Important rootstocks in different fruit crops. Biotech articles

Goswami, A. M., Saxena, K., \& Kurein, S. (1993). High density planting in citrus. in. Advances in Horticulture, K. L. Chadha and O. P. Pareek (eds.). Malhotra Publishing House, New Delhi, India

Guswomi, A. K., Prakash, J., \& Singh, A. K. (2014). High Density Planting System in tropical fruits, Horticulture flora. Research Spectrum, 3(3), 298-300.

Hutton, R. J. (1986). The influence of tree size control and plant density on citrus productivity. Acta Horticulture, 175, 249-254. https://doi.org/10.17660/ActaHortic.1986.175.36

Jhade, R. K. (2016.) Studies on effect of growth substances on crop regulation and yield of Nagpur mandarin (Citrus reticulate Blanco) under water deficit stress condition. Ph.D thesis, Jawaharlal Nehru Krishi Vishwa Vidalaya, Jabalpur, India

Klerk, J. (2017). Citrus pruning learners guide, Citrus academy, Citrus international research, $1,4-6$. 


\section{$\triangle$ Macrothink}

Journal of Agricultural Studies

ISSN 2166-0379

2019, Vol. 7, No. 2

Legua, P., Forner, J. B., Hernández, F., \& Forner-Giner, M. A. (2013). Physicochemical properties of orange juice from ten rootstocks using multivariate analysis. Sci Hortic. 160, 268-273. https://doi.org/10.1016/j.scienta.2013.06.010

Legua, P., Forner, J. B., Hernández, F., \& Forner-Giner, M. A. (2014). Total phenolics, organic acids, sugars and antioxidant activity of mandarin (Citrus clementina Hort. ex Tan.): variation from rootstock. Sci Hortic. 174, 60-64.

https://doi.org/10.1016/j.scienta.2014.05.004

Lockard, R. G., \& Schneider, G. W. (1978). Advances in the concept of the dwarfing mechanism in apple. Horticultural Review 3, 315-376

Mademba-Sy, F., Lemeire-Desprez, Z., \& Lebegin, S. (2012). Use of Fly Dragon Trifoliate Orange as Dwarfing Rootstock for Citrus under Tropical climatic Conditions. American Society of Horticulture Science, 47(1), 11-17. https://doi.org/10.21273/HORTSCI.47.1.11

Martínez-Alcántara, B, Rodriguez-Gamir, J., Martínez-Cuenca, M. R., Iglesias, D. J., Primo-Millo, E., \& Forner-Giner, M. A. (2013). Relationship between hydraulic conductance and citrus dwarfing by the Flying Dragon rootstock (Poncirus trifoliata L. Raft var. monstruosa). Trees. 27, 629-638. https://doi.org/10.1007/s00468-012-0817-1

MC Carry, C. D., Brown, G. K., \& Burkner, P. I. (1969). Citrus Tree and modification to facilates mechanical harvest

Nawaj, M. A., Ahmed, W., Iqbal, Z., \& Khan, M. M. (2007). Evaluation of high density plantation on vigor and yield in kinnow mandarin (Citrus reticula Blanco). Institute of Horticulture Sciences, University of Agiculture, Faisalabad, Pakistan

Nemec, S. (1978). Proceeding; Florida State of Horticulture Society, 91, 10-14.

Palmer, J. W., \& Wertheim, S. J. (1981). Effects of Tree Density on Fruit Quality. ISHS Acta Horticultrae, 114. https://doi.org/10.17660/ActaHortic.1981.114.15

Palmer. J. (2004). High Density Planting System: Principles and Pitfalls, Horticulture Research. Nelson Research Centre, Newzealand.

Sakaria, M., \& Tao, Z. (2000). 309 Rapid Growth of Microbuded Citrus Planted Ultra-high Density. American Society for Horticulture Science, 35(3), 445.

https://doi.org/10.21273/HORTSCI.35.3.445C

Salomon, E. (1981). Effect of CCC on Growth, Distributing and Fruiting in Citrus. ISHS Acta Horticultarae. 114. https://doi.org/10.17660/ActaHortic.1981.114.20

Schumann, A., Hostler, K., \& Waldo, L. (2012). Advanced citrus production systems- grove designs for higher efficiencies, Citrus Industry.

Sheheilah, F. (2013). Identification of export opportunities for Syrian Citrus growers to EU: A supply chain perspective. Dissertion at department of Agricultural economics and Rural development, Georg-August University of Gottingen.

Shrestha P. P., \& Verma, S. K. (1998). Development and outlook of citrus industry in Nepal. Nepalese Horticulture, 2(1), 48-57. 
Shrestha, G. K. (2010). High Density Planting and it's Implication in Fruit Industry, Research gate

Singh, S., \& Singh, R. K. (2018). Density concept of orcharding. International journal of advance scientific research and management. Special issue 1, India

Skewes, M. (2016). Citrus rootstock technical guide: Mature tree assessment, South Australian research and development institute. Retrived from: https://pir.sa.gov.au/_data/assets/pdf_file/0010/296902/Citrus_Technical_Guide.pdf

Smith, R. (2002). High density grove management: a matter of planning, Tree source Citrus nursery news. Retrived from:

http://www.citrustreesource.com/Resources/TSN\%20Winter\%202002\%20NL.pdf

Tucker, D. P. H. \& Wheaton, T. A. (1978). Spacing trends in Higher Citrus planting Densities. Proceeding of Florida State Horticulture Society, 91, 36-46.

Tucker, D. P. H., \& Muraro, R. P. (1990). A High Density Planting, Proceeding of Florida State. Horticulture Society, 103, 55-59.

Tucker, D. P. H., Wheaton, T. A., \& Muraro, R. P. (1994). Citrus Tree Pruning and Practices, University of Florida, Fact Sheet HS-144 June 1994. Retrived from: https://counties.agrilife.org/harris/files/2011/05/Citrus-Pruning.pdf

Vandan, S. P., Solanki, S., \& Lamo, K. (2017). Canopy Management: Way to Develop Fruit Tree Architecture. Biomolecules Reports.

Wertheim, S. J. (1981). High Density Planting: Development and Current Achievements in the Netherlands, Belgium and West Germany. ISHS Acta Horticultrae, 114. https://doi.org/10.17660/ActaHortic.1981.114.44

Wheaton, J. D., Castle, T. A., \& Tucker, W. S. (1994). Optimizing orange growth factors for fruit production and harvesting. Transaction of the ASAE, 365-371. https://doi.org/10.13031/2013.28086

Wheaton, T. A. (1995). Tree Vigor important in Citrus tree spacing and topping, Proceeding of Florida State Horticulture Society, 108, 63-69.

Wheaton, T. A., Castle, W. A., \&Tucker, D. P. H. (1994). Performance of Citrus scion cultivars and rootstocks in high density planting. Horticulture Science, 20(7), 837-840. https://doi.org/10.21273/HORTSCI.26.7.837

Wright, G. C., \& Kelly, J. (2008). Pruning Citrus, The University of Arizona, College of Agriculture and Life Sciences, USA

\section{Copyright Disclaimer}

Copyright for this article is retained by the author(s), with first publication rights granted to the journal.

This is an open-access article distributed under the terms and conditions of the Creative Commons Attribution license (http://creativecommons.org/licenses/by/3.0/). 